\title{
Effects of Inhaling Essential Oils from Lavender, Silver Fir, Grapefruit on the Restraint Stress in Mice
}

\author{
Seun-Ah Yang, Sang-Kyung Jeon', Eun-Jung Lee', Nam-Kyung Im $^{1}$, Chang-Hyun Shim² and \\ In-Seon Lee'*
}

\author{
The Center for Traditional Microorganism Resources, Keimyung University, Daegu, 704701, Korea \\ ${ }^{1}$ Department of Food Science of Technology, Keimyung University, Daegu, 704701, Korea \\ ${ }^{2}$ MENTech Co., Ltd, Daegu 704948, Korea
}

Received June 3, 2010 / Accepted July 23, 2010

\begin{abstract}
The effects of inhaling three essential oils (lavender [Lavendular angustifolia], silver fir [Abies alba], and grapefruit [Citrus paradise]) against restraint stress were investigated in mice. Serum cortisol levels were significantly increased in the 1h-restraint group. Also, silver fir and grapefruit oils prevented the elevation of cortisol levels under experimental conditions. Inhalation of $10 \%$ lavender oil for $30 \mathrm{~min}$ before inducing stress significantly inhibited restraint-induced hypothermia. We also investigated the effects of restraint stress on triglycerides, total cholesterol, and high-density lipoprotein cholesterol. It was found that the concentration of triglycerides in the serum samples increased after restraint stress. Silver fir essential oil inhibited elevation of triglyceride levels. Taken all together, the correlation of herb essential oil inhalation against restraint stress in animals can partly be explained.
\end{abstract}

Key words : Inhaling essential oil, anti-stress, restraint, serum cortisol, hypothermia, antiradical capacity

\section{서 론}

허브 정유는 항산화, 항염증, 항균 등의 다양한 생체 조절능 을 나타내는 활성성분을 함유하고 있어서 향기요법 외에 식품 이나 화장품 산업에 널리 이용되고 있다. 특히, 합성 항산화제 나 방부제 등의 합성첨가제의 독성이 알려지면서 이를 대체하 기 위한 천연 허브 정유의 이용에 관심이 높아지고 있다. 천연 허브의 꽃이나 잎도 건조하여 이용되고 있으나 성분이 변질되 기 쉽고 일정한 효과를 얻기 힘든 반면, 정유는 순도가 높은 고품질의 허브 오일을 이용하여 항상 같은 효과를 얻을 수 있다. 정유의 알려진 효능으로는 향기의 종류에 따라 정신기 능을 진정[6,8,18] 또는 자극[21], 항우울[16], 숙면효과[11], 진 경작용[12], 면역증진[7,23], 스트레스 감소[22,25], 혈중 카테콜 아민과 코티졸 농도의 감소[15] 등이 보고되었고, 항우울 또는 불안감소 효과는 약물과 함께 사용 시 약물의 부작용으로 문 제가 되는 우울증과 불안감 등을 예방하고 약물의 복용량을 줄일 수 있는 것으로 알려졌다. 정유는 케톤, 알데히드, 테르 펜, 에스테르, 옥사이드 및 알코올 등의 휘발성 성분들에 의해 고유의 향과 다양한 효능을 나타내며, 이러한 향기성분이 호 흡기계나 피부를 통하여 신경계로 전달되어 생리적, 심리적인 스트레스 반응과 면역기능 조절 효과를 나타낸다. 정유를 이

*Corresponding author

Tel : +82-53-580-6449, Fax : +82-53-580-6447

E-mail : inseon@kmu.ac
용한 다양한 대체요법이 소개되고 있으나, 그 중 흡입에 의한 효과가 가장 빠르게 나타나는 것으로 알려져 있다[19]. 일반적 으로 폭넓게 사용되고 있는 라벤더 오일은 다량의 에스터를 함유하며, 심리적 안정과 스트레스 완화, 피부의 혈행을 증진, 숙면효과 등의 효능이 보고되어 있다[2,10,14,17,24]. 특히, 라 벤더 오일의 항산화 활성은 동맥경화와 같은 퇴행성 질환의 개선과도 관련이 있으며, 향의 흡입 후 혈청 코티졸 농도의 감소와 관상동맥혈류 개선되는 효과가 보고되었다[24]. 오렌 지 오일도 심리적 상태를 변화시켜서 마음을 안정시키는 작용 [20]을 하는 반면에, 로즈마리 오일은 다량의 옥사이드를 함유 하고 신경계를 자극하여 각성효과를 나타낸다[21]. 이와 같이 정유는 폭넓게 이용되고 있으나 정유의 성분이나 정유의 종류 에 따른 효능 및 작용의 차이에 관한 과학적인 근거는 부족한 실정이며 흡입에 의한 작용에 대한 보고는 매우 적다. 또한, 일반적으로 사용되는 정유의 효과에 대한 자료는 몇 가지의 허브에 집중되어 있으며 추출방법, 재배시기, 사용부위 등에 따른 상반되는 보고로 인하여 소비자가 시판 허브 정유의 활용 을 위한 선정 시 어려움이 있다. 한편, 정유의 스트레스 완화 효과와 관련된 연구에서 동물실험의 경우, 배고픔, 한냉, 구속, 전기충격 등과 같은 인위적인 급성 스트레스원을 사용하는 반 면, 인간의 스트레스는 이보다 강도는 약하나 다양하며 만성적 인 특징을 갖고 있다. 마우스의 구속 스트레스에 대한 정유 흡입의 효능을 테스트하기에 앞서 실제로 아로마테라피 등에 많이 사용되고 있는 시판 정유의 효능을 비교하여 그 생리활성 
과 항스트레스 효능의 연관성을 분석하기 위하여, 전보에서는 티트리 등의 8가지 정유[27-29]의 향기성분 분석, 항산화 및 항 균 효과에 대하여 보고하였다. 본 연구에서는 정유 향 흡입의 항스트레스 효과를 마우스를 이용하여 테스트하기 위하여, 이 중 정유 향의 선호도가 높고 심신의 안정 효과가 알려져 있으 며 라디컬 소거능에 차이가 있는 라벤더, 실버퍼, 그레이프후 룻 오일을 선정하여 각각 10 배( $10 \%$ 오일), 500 배 $(0.2 \%$ 오일) 희석한 후 구속 스트레스에 대한 완화 효과를 측정하였다.

\section{재료 및 방법}

\section{Essential oil}

본 연구에 사용된 정유는 라벤더(Lavendular angustifolia, Australia, 증류추출), 그레이프후룻(Citrus paradise, Florida, 압착 추출), 실버퍼(Abies alba, Austria, 증류추출) 정유로 Skinmate 사(Puchon, Gyeonggi-do, Korea)에서 구입하였으며, 사용 전 까지 갈색병에 넣어서 밀봉 후 $4^{\circ} \mathrm{C}$ 에서 냉장 보관하였다.

\section{실험동물과 향기 흡입}

실험에 사용된 생쥐는 7 주령의 체중 약 $32 \pm 3 \mathrm{~g}$ 의 ICR계 수컷 마우스 (오리엔트바이오, 경기도, 한국)로서 항온, 항습이 유지되는 본 센터의 동물사육실(실내온도, $24-26^{\circ} \mathrm{C}$ ) 내에서 물 과 사료를 충분히 섭취하게 하면서 환경에 2 주간 적응시킨 후 사용하였다. 각 그룹별로 7-9 마리의 마우스를 한 그룹으로 하였으며, 정유 향을 흡입시키는 그룹은 투명 cage $(27 \times 22 \times 13$ $\mathrm{cm})$ 안에 정유 $5 \mathrm{ml}$ 을 $14 \mathrm{ml}$ 의 깨끗한 튜브에 넣어 위를 열어 둔 상태로 고정하여 30 분 후에 생쥐를 넣어서 30 분간 향을 흡입시킨 후 구속스트레스를 가하였다. 정유는 $50 \pm 3^{\circ} \mathrm{C}$ 의 증 류수로 10 배, 500 배 희석하여 사용하였다.

\section{급성 구속 스트레스}

생쥐를 각각 선단을 절개한 $50 \mathrm{ml}$ 튜브 $(2.8 \times 2.8 \times 11.5 \mathrm{~cm})$ 에 넣어서 30 분, 1 시간, 2.5 시간 넣어서 스트레스를 가한 후 계속 해서 실험에 사용하였다.

\section{혈청 코티졸 측정}

스트레스 호르몬의 마커로 알려진 혈청 코티졸 농도를 측정 하기 위하여, 생쥐에 구속 스트레스를 가한 후 희생, 심장에서 채혈하여 실온에서 30 분간 방치 후 15 분간 $3,000 \mathrm{rpm}$ 에서 원 심분리 하여 혈청을 분리, Coat-A-Count cortisol kit (Siemens Healthcare Diagnostics, Los Angeles, USA)를 이용하여 방사 면역분석법(Radioimmunoassay)으로 측정하였다. 분리된 혈 청은 분석까지 $4^{\circ} \mathrm{C}$ 에서 냉장보존 하였다.

\section{혈청 총 콜레스테롤과 중성지질 값 측정}

혈청 총 콜레스테롤, 중성지방, 고밀도 리포단백 질 콜레스
테롤(HDL-cholesterol)을 효소법(Daiichi Pure Chemicals Co., Ltd., Tokyo, Japan)으로 측정하였다.

\section{체온 측정}

구속 스트레스 전후의 체온 측정은 동물용 디지털 체온계 (SUMMIT SDT8A, 인천, 한국)를 이용하였으며, 체온계를 생 쥐의 항문에 $2 \mathrm{~cm}$ 삽입하여 20 초간 측정하였다.

\section{결과 및 고찰}

구속 시간에 따른 코티졸 함량 변화 및 정유 향 흡입의 영향 스트레스 반응을 측정하기 위한 생리적 지표는 다양하지만, 혈청의 코티졸 함량 변화를 측정하여 급성 구속 스트레스에 대한 정유의 효과를 판단하기 위하여, 먼저 구속 시간(30분, 1 시간, 2.5 시간)에 따른 혈청내의 코티졸 함량 변화를 측정하 였다. 그 결과, 스트레스의 마커로 사용된 코티졸은 구속 전에 는 $0.07 \pm 0.02 \mathrm{mg} / \mathrm{dl}$ 였으며, $0.5,1,2.5$ 시간 경과에 따라 $0.76 \pm 0.05,1.15 \pm 0.17,0.58 \pm 0.10 \mathrm{mg} / \mathrm{dl}$ 로 변화하여 1 시간 구속 시 크게 증가하는 것을 알 수 있었다(Fig. 1A). 본 실험에서는, 혈중 코티졸 농도가 1 시간 구속 스트레스를 가한 경우 가장 크게 증가하였으므로 1 시간 구속 후 정유의 흡입 효과를 비교 하였다. 1 시간 구속의 조건에서 코티졸 농도를 측정한 결과, 라벤더 오일은 $10 \%$ 의 고농도에서 스트레스 콘트롤의 $56.7 \%$ 로 혈청 코티졸 농도가 유의적으로 감소하였으나 저농도에서는 유의적인 차가 없었다. 실버퍼와 그레이프후룻 오일의 흡입에 서는 $0.2 \%$ (각각 $63.1 \%, 52.3 \%$ )와 $10 \%$ (각각 $30.9 \%, 39.5 \%$ ) 오일 에서 모두 유의적인 저하를 나타냈으며, $10 \%$ 실버퍼 오일에서 스트레스 완화 효과가 가장 크게 나타났다(Fig. 1B). 이와 같은 코티졸의 변화에 대한 정유 흡입의 영향과 관련된 최근의 보 고로서, 스트레스 반응에 대한생물학적 표지자로 이용되는 타 액의 코티졸, secretory IgA, 알파 아밀라아제와 같은 활성 성 분들이 정유 향 흡입과 밀접한 관계가 있음이 알려졌으며[5], 분노와 같은 신체적 스트레스가 혈중의 활성산소종(ROS)과 코티졸의 농도를 증가시키는 것으로 보고되었다[3].

\section{스트레스에 따른 정유 향 흡입의 체온변화 억제효과}

1 시간의 구속스트레스 전 30 분간 각각의 정유 향을 흡입시 킨 후, 스트레스 전후의 체온을 동물용 디지털 체온계를 이용 하여 측정하였다. 그 결과, 1 시간의 구속 스트레스로 인하여 체온이 $38.7^{\circ} \mathrm{C}$ 에서 $36.9^{\circ} \mathrm{C}$ 로 저하되는 것을 확인하였으며, $10 \%$ 의 라벤더 오일 흡입에 의해 체온 저하가 $38.5^{\circ} \mathrm{C}$ 로 유지되 는 것을 알 수 있었다(Fig. 2). 그 외의 정유 흡입으로는 체온 저하에 대한 유의적인 억제효과는 나타나지 않았다. 이러한 스트레스로 인한 저 체온 증상은 Amar and Sanyal [1]과 van Eijl 등[26]의 연구에서도 쥐와 마우스를 이용한 구속 스트레스 에 의해 체온의 저하가 나타남이 보고 되었다. 


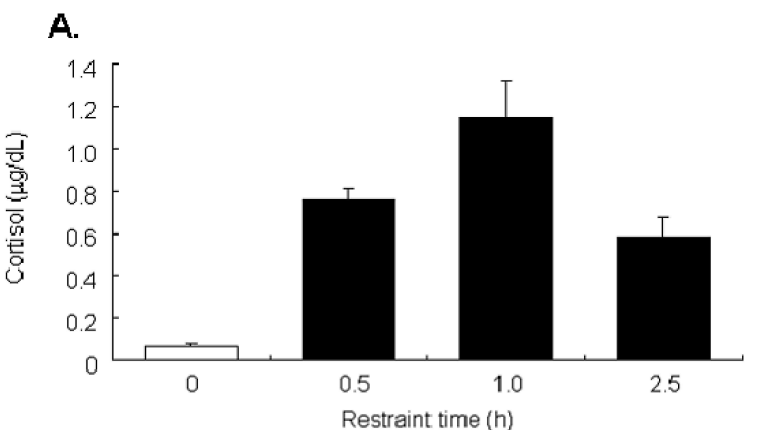

B.

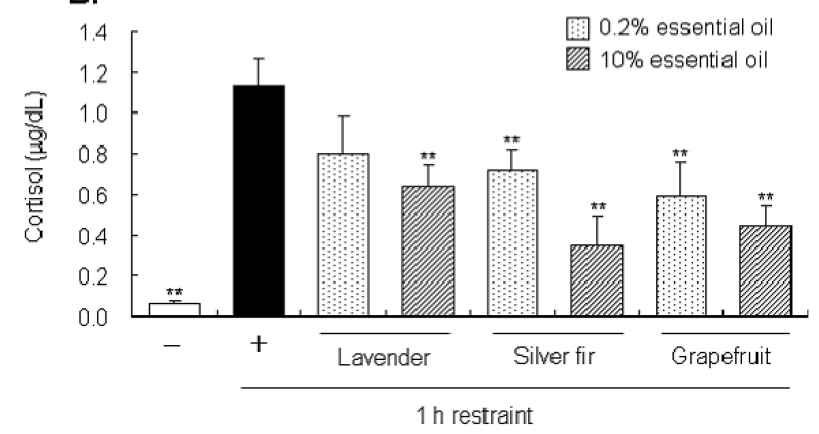

Fig. 1. Changes in serum cortisol level by the restraint stress (A) and by the smells of 3 different essential oils (B). Each of the 7 or 9 mice per group were immobilized individually in a 50-ml tube for the indicated time. Serum was collected immediately after the stress, and cortisol level was measured as described in the "Methods" section. The essential oils of lavender, silver fir, and grapefruit were diluted 500 times $(0.2 \%)$ and 10 times $(10 \%)$ with distilled water of $50 \pm 3^{\circ} \mathrm{C}$ to prepare the test solutions. Five $\mathrm{ml}$ of the test solution was added to clean 14-ml tube, and the tubes were placed in each cage for $30 \mathrm{~min}$ prior to the $1 \mathrm{hr}$ immobilization. Significant differences vs. stress-control group (distilled water-treated) were calculated two-tailed student's $t$-tests $\left({ }^{*} p<0.05,{ }^{* *} p<0.01\right)$.

\section{혈청 총 콜레스테롤 및 중성지질에의 영향}

스트레스와 혈액 지질성분의 농도와 관련, 또는 정유 향의 투여나 흡입과 혈액 지질성분의 농도의 변화와 관련하여 몇 가지의 보고가 있으나 직접적인 상관관계가 있는지는 불확실 한 상태이다. 따라서 마우스를 이용한 본 실험에서는, 스트레 스 마커인 코티졸 외의 혈중 총 콜레스테롤 및 중성지질 농도 가 스트레스와 허브 오일 향의 흡입으로 변화하는지 알아보기 위하여 30 분간 향을 흡입시키고 구속 스트레스를 가한 후 혈 청의 콜레스테롤과 중성지질 함량을 측정하였다. 그 결과, 총 콜레스테롤의 농도에는 향 흡입 전후에 변화가 없었으나, 중 성지질의 함량은 구속스트레스에 의해 유의적으로 증가하였 으며, 향 흡입으로 $0.2 \%$ 라벤더 오일을 제외한 군에서 유의적 으로 감소되는 것을 알 수 있었다(Fig. 3).

스트레스로 인한 혈중 지질 농도의 변화와 관련된 보고는

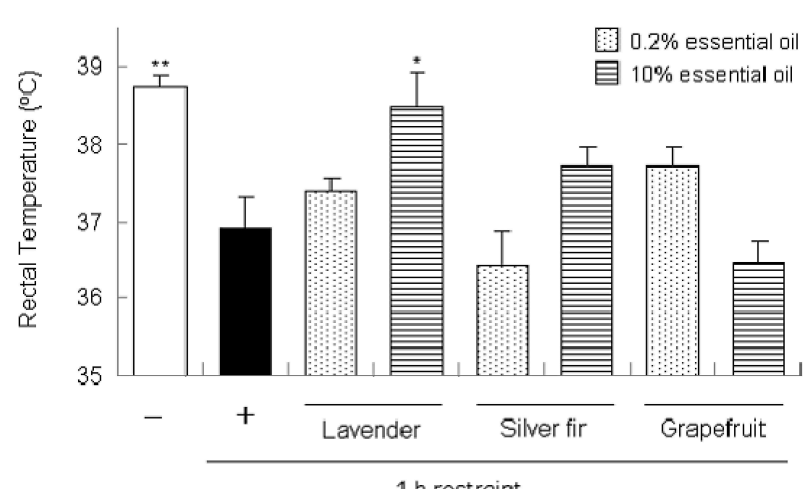

Fig. 2. Effects of inhaling the essential oils on the hypothermia induced by immobilization for $1 \mathrm{hr}$. Inhalation of essential oil was performed for $30 \mathrm{~min}$ before the stress. Significant differences vs. stress-control group (distilled water-treated) were calculated two-tailed student's $t$-tests $\left({ }^{*} p<0.05,{ }^{* *} p<0.01\right)$.

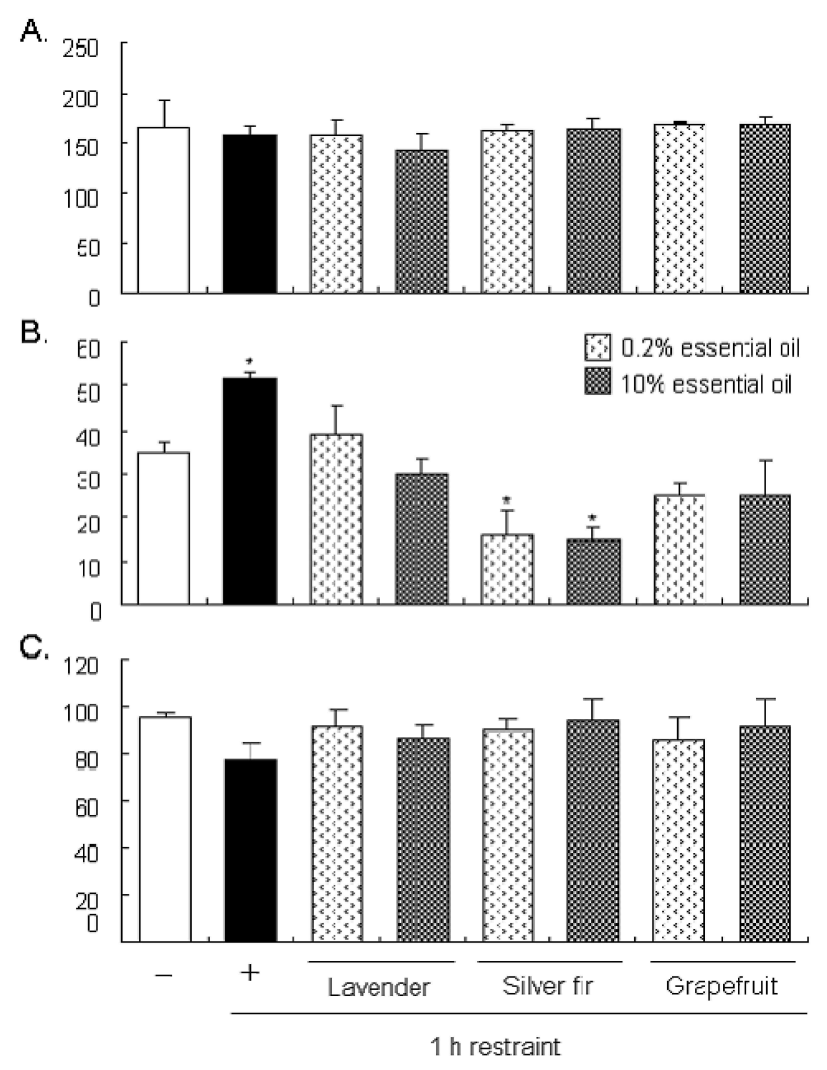

Fig. 3. Effects of inhaling the essential oils on the changes of total cholesterol, triglyceride, and HDL cholesterol induced by immobilization stress for $1 \mathrm{hr}$. Serum was collected immediately after the stress, and total cholesterol (A), triglyceride (B), and HDL cholesterol (C) levels were measured as described in Methods section. Inhaling essential oil was performed for $30 \mathrm{~min}$ before the stress. Significant differences vs. no stress-control group were calculated two-tailed student's $t$-tests $\left({ }^{*} p<0.05,{ }^{* *} p<0.01\right)$. 
많지 않으나, Hershocka and Wolfgang [13]은 마우스 혈장의 중성지질 농도가 구속 스트레스 후에 대조군에 비해 높은 것 을 보고하였고, 정 등[9]은 마우스에 정유 투여 시 콜레스테롤 치를 낮추는 효능이 나타났다고 보고하였다. 또한, 최근에는 천연의 정유 향이 신체의 항산화능에 미치는 영향에 관한 연 구에 관심이 높아지고 있으며, 타액의 DPPH 라디컬 소거능이 신체적, 정신적 스트레스에 의해 저하되고 정유 향의 흡입에 의해 증가되는 것이 보고되어 스트레스와 신체의 항산화능과 의 직접적인 상관관계가 시사되었다[4]. 그러나 혈액의 총 콜 레스테롤에 대한 정유 향 흡입의 영향은 확실치 않으며, 스트 레스로 인한 중성지질의 증가에 대한 정유 향 흡입의 완화 효과를 체계적으로 설명하기 위해서는 좀 더 심층적인 실험이 필요할 것으로 사료된다.

\section{감사의 글}

본 연구는 지식경제부 지정 계명대학교 전통자원개발 및 산업화연구센터의 지원으로 수행되었음에 감사 드립니다.

\section{References}

1. Amar, A. and A. K. Sanyal. 1981. Immobilization stress in rats: effect on rectal temperature and possible role of brain monoamines in hypothermia. Psychopharmacol. (Berl) 73, $157-160$

2. Arzi, A., L. Sela, A. Green, G. Givaty, Y. Dagan, and N. Sobel. 2010. The influence of odorants on respiratory patterns in sleep. Chem Senses 35, 31-40.

3. Atanackovic, D., M. C. Brunner-Weinzierl, H. Kroger, S. Serke, and H. C. Deter. 2002. Acute psychological stress simultaneously alters hormone levels, recruitment of lymphocyte subsets, and production of reactive oxygen species. Immund. Invest. 31, 73-91.

4. Atsumi, T. and K. Tonosaki. 2003. Free radical scavenging activity in saliva induced by aromas. Jpn. J. Taste Smell Res. $10,815-818$

5. Atsumi, T. and K. Tonosaki. 2007. Smelling lavender and rosemary increases free radical scavenging activity and decreases cortisol level in saliva. Psychiatry Res. 150, 89-96.

6. Buchbauer, G., L. Jirovetz, W. Jäger, C. Plank, and H. Dietrich. 2003. Fragrance compounds and essential oils with sedative effects upon inhalation. J. Pharm Sci. 82, 660-664.

7. Carrasco, F. R., G. Schmidt, A. L. Romero, J. L. Sartoretto, S. M. Caparroz-Assef, C. A. Bersani-Amado, and R. K. Cuman. 2009. Immunomodulatory activity of Zingiber officinale Roscoe, Salvia officinalis L. and Syzygium aromaticum L. essential oils: evidence for humor- and cell-mediated responses. J. Pharm Pharmacol. 61, 961-967.

8. Cavanagh, H. M. and J. M. Wilkinson. 2002. Biological activities of lavender essential oil. Phytother. Res. 16, 301-308.

9. Chung, M. J., K. W. Park, K. H. Kim, C. T. Kim, J. P. Baek,
K. H. Bang, Y. M. Choi, and S. J. Lee. 2008. Asian plantain (Plantago asiatica) essential oils suppress 3-hydroxy-3-methyl-glutaryl-co-enzyme A reductase expression in vitro and in vivo and show hypocholesterolaemic properties in mice. Br. J. Nutr. 99, 67-75.

10. Daferera, D. J., B. N Ziogas, and M. G. Polissiou. 2000. GC-MS analysis of essential oils from some Greek aromatic plants and their fungitoxicity on Penicillium digitatum $J$. Agric. Food Chem 48, 2576-2581.

11. Field, T, T. Field, C. Cullen, S. Largie, M. Diego, M, S. Schanberg, and C. Kuhn. 2008. Lavender bath oil reduces stress and crying and enhances sleep in very young infants. Early Hum Dev. 84, 399-401.

12. Franca, C. S., F. S. Menezes, L. C. Costa, E. S. Niculau, P. B. Alves, J. E. Pinto, and R. M. Marçal. 2008. Analgesic and antidiarrheal properties of Ocimum selloi essential oil in mice. Fitoterapia 79, 569-573.

13. Hershocka, D. and H. V. Wolfgang. 1989. The effects of immobilization stress on serum triglycerides, nonesterified fatty acids, and total cholesterol in male rats after dietary modifications. Life Sci. 45, 157-165.

14. Howard, S., and B. M. Hughes. 2008. Expectancies, not aroma, explain impact of lavender aromatherapy on psychophysiological indices of relaxation in young healthy women. Br. J. Health Psychol. 13, 603-617.

15. Hwang, J. H. 2006. The effects of the inhalation method using essential oils on blood pressure and stress responses of clients with essential hypertension. Taehan Kanho Hakhoe Chi. 36, 1123-1134.

16. Kabuto, H., M. Tada, and M. Kohno. 2007. Eugenol [2-methoxy-4-(2-propenyl)phenol] prevents 6-hydroxydopamine-induced dopamine depression and lipid peroxidation inductivity in mouse striatum. Biol. Pharm Bull. 30, 423-427.

17. Linck, V. M., A. L. da Silva, M. Figueiró, A.L. Piato, A. P. Herrmann, F. Dupont Birck, E. B. Caramão, D. S. Nunes, P. R. Moreno, and E. Elisabetsky. 2009. Inhaled linalool-induced sedation in mice. Phytomedicine 16, 303-307.

18. Lis-Balchin, M., and S. Hart. 1999. Studies on the mode of action of the essential oil of lavender (Lavandual angustifolia P. Miller). Phytother. Res. 13, 540-542.

19. Oh, H. K., J. Y. Choi, K. K. Chun, J. S. Lee, D. K. Park, S. D. Choi, T. I. Chun, M. K. Kim, and S. B. Kim. 2001. A study for antistress effects of two aromatic synergic blending oils. J. Korean Soc. Jungshin Sci. 14, 33-49.

20. Reiter, M., and W. Brandt. 1985. Relaxant effects on tracheal and ileal smooth muscles of the guinea pig. Arzneimittel-Forsch 35, 408-414.

21. Sanders, C., M. Diego, M. Fernandez, T. Field, M. Hernandez-Reif, and A. Roca. 2002. EEG asymmetry responsesto lavender and rosemary aromas in adults and infants. Int. J. Neurosci. 112, 1305-1320.

22. Seo, J. Y. 2009, The effects of aromatherapy on stress and stress responses in adolescents. J. Korean Acad Nurs. 39, 357-365.

23. Serafino, A., P. Sinibaldi Vallebona, F. Andreola, M. Zonfrillo, L. Mercuri, M. Federici, G. Rasi, E. Garaci, and 
P. Pierimarchi. 2008. Stimulatory effect of Eucalyptus essential oil on innate cell-mediated immune response. BMC Immunol. 18, 9-17.

24. Shiina, Y., N. Funabashi, K. Lee, T. Toyoda, T. Sekine, S. Honjo, R. Hasegawa, T. Kawata, Y. Wakatsuki, S. Hayashi, S. Murakami, K. Koike, M. Daimon, and I. Komuro. 2008. Relaxation effects of lavender aromatherapy improve coronary flow velocity reserve in healthy men evaluated by transthoracic Doppler echocardiography. Int. J. Cardiol. 129, 193-197.

25. Son, K. C., J. E. Song, S. J. Um, K. Y. Paek, H. K. Oh, J. S. Lee, and J. H. Kim. 2001. Effects of absorption of essential oils on the changes of arousal and antistress. J. Korean Soc. Hort. Sci. 42, 614-620.

26. van Eijl, S. R., van Oorschot, B. Olivier, F. P. Nijkamp, and
N. Bloksma. 2006. Stress and hypothermia in mice in a nose-only cigarette smoke exposure system. Inhal. Toxicol. 18, 911-918.

27. Yang, S. A., S. K. Jeon, E. J. Lee, N. K. Im, J. Y. Jung, and I. S. Lee. 2008. Bioactivity and chemical composition of the essential oil of tea tree (Melaleuca alternifolia). J. Life Sci. 18, 1644-1650.

28. Yang, S. Y., S. K. Jeon, E. J. Lee, N. K., Im, K. H. Jhee, S. P. Lee, and I. S. Lee 2009. Radical Scavenging Activity of the Essential Oil of Silver Fir (Abies alba). J. Clin. Biochem Nutr. 44, 253-259.

29. Yang, S. A., S. K. Jeon, E. J. Lee, C. H. Shim, and I. S. Lee. 2010. Comparative study of the chemical composition and antioxidant activity of six essential oils and their components. Nat. Prod Res. 24, 140-151.

초록 : 라벤더, 실버퍼, 그레이프후룻 정유 흡입이 마우스의 구속 스트레스에 미치는 효과

양선아 · 전상경 ${ }^{1} \cdot$ 이은정 ${ }^{1}$ - 임남경 $\cdot$ 심창현 ${ }^{2} \cdot$ 이인선 ${ }^{1} *$

(계명대학교 전통미생물자원개발 및 산업화연구센터, ${ }^{1}$ 계명대학교 식품가공학과, ${ }^{2}$ (주)맨텍)

천연 허브에서 추출된 정유의 스트레스 완화능이 알려지면서 화장품, 식품 산업뿐 아니라 다양한 기능성 제품 에 활용되고 있다. 본 연구에서는 정유 향 흡입의 스트레스 완화 효과에 대한 과학적인 근거를 마련하기 위하여 마우스의 구속 스트레스에 대한 3 가지 정유의 흡입 효과를 비교 하였다. 마우스를 1 시간 구속한 경우 혈청 코티 졸 농도의 유의적인 상승, 체온의 저하 및 혈중 중성지질의 상승을 확인하였으며, $10 \%$ 라벤더 오일을 30 분간 흡 입 한 경우, 혈청 코티졸 농도 상승 및 체온 저하가 유의적으로 억제되어 스트레스 완화 효과가 가장 좋았다. 한편 혈중 중성지질의 증가 억제효과는 실버퍼 오일 흡입에서 유의적으로 감소하였다. 본 연구에서는 폭넓게 사 용되는 정유를 이용하여 정유 향 흡입의 스트레스 완화 효과를 측정 함으로서 앞으로의 연구와 활용에 대한 기본 적인 과학적 근거를 마련하였다. 